\title{
PENGGUNAAN SUPPORT VECTOR REGRESSION DALAM PEMODELAN INDEKS SAHAM SYARIAH INDONESIA DENGAN ALGORITME GRID SEARCH*
}

\author{
Galih Hedy Saputra $^{1}$, Aji Hamim Wigena ${ }^{2 \ddagger}$, and Bagus Sartono ${ }^{3}$
}

\author{
${ }^{1}$ Department of Statistics, IPB University, Indonesia, galihhedy@gmail.com \\ ${ }^{2}$ Department of Statistics, IPB University, Indonesia, ajiwigena@ymail.com \\ ${ }^{n}$ Department of Statistics, IPB University, Indonesia, bagusco@ipb.ac.id \\ $\ddagger$ corresponding author
}

\section{Indonesian Journal of Statistics and Its Applications (eISSN:2599-0802)}

Vol 3 No 2 (2019), 148 - 160

Copyright (c) 2019 Galih Hedy Saputra, Aji Hamim Wigena, and Bagus Sartono. This is an open-access article distributed under the Creative Commons Attribution License, which permits unrestricted use, distribution, and reproduction in any medium, provided the original work is properly cited.

\begin{abstract}
Indonesia as the largest Muslim population country in the world is a very potential market for sharia stocks. Sharia stocks performance can be seen from the Indonesia Sharia Stock Index (ISSI). Stock index modeling is conducted to determine the factors that affect the stock index or to predict the value of the stock index. Modeling using regression analysis is based on assumptions that do not always match with the characteristics of stock data that fluctuate. Support Vector Regression (SVR) method is a non-parametric approach based on machine learning. The problem often encountered in the analysis using SVR is to determine the optimal parameters to produce the best model. The determination of the optimal parameters can be solved by using the grid search algorithm. The purpose of this research is to make ISSI model using SVR with grid search algorithm with independent variable BI Rate, money supply, and exchange rate (USD / IDR). The best SVR model was obtained using weekly data with a total of 343 periods as well as a linear kernel with parameters $\epsilon=0.03$ and $\mathrm{C}=2$. The evaluation of the best model SVR is RMSE of 2.289 and correlation value of 0.873 .
\end{abstract}

Keywords: grid search, ISSI, saham, SVR, syariah.

\footnotetext{
*Received Oct 2018; Accepted Apr 2019; Published online on Juni 2019
} 


\section{Pendahuluan}

Indonesia sebagai negara dengan jumlah penduduk muslim terbesar di dunia merupakan pasar yang sangat besar dan potensial untuk pengembangan pasar modal syariah, tidak terkecuali saham syariah. Saham syariah merupakan saham yang tidak bertentangan dengan prinsip-prinsip syariah seperti tidak mengandung unsur judi, riba, dan ketidakpastian. Kinerja saham syariah yang beredar dapat dilihat dari Indeks saham syariah. salah satu indeks saham syariah yang digunakan di Indonesia, yaitu Indeks Saham Syariah Indonesia (ISSI).

Menurut Bursa Efek Indonesia (BEI (2018)) ISSI merupakan indeks saham yang mencerminkan keseluruhan saham syariah yang tercatat di BEI. Konstituen ISSI adalah keseluruhan saham syariah tercatat di BEI dan terdaftar dalam Daftar Efek Syariah (DES). Konstituen ISSI didata ulang setiap 6 bulan sekali (Mei dan November) dan dipublikasikan pada awal bulan berikutnya. Konstituen ISSI juga dilakukan penyesuaian apabila ada saham syariah yang baru tercatat atau dihapuskan dari DES. Metode perhitungan indeks ISSI menggunakan rata-rata tertimbang dari kapitalisasi pasar. Tahun dasar yang digunakan dalam perhitungan ISSI adalah awal penerbitan DES yaitu Desember 2007. Indeks ISSI diluncurkan pada tanggal 12 Mei 2011.

Para investor yang akan berinvestasi pada saham syariah perlu pertimbangan yang matang tentang faktor-faktor yang mempengaruhi indeks saham syariah. Faktor-faktor yang memengaruhi indeks saham syariah menurut Pasaribu and Firdaus (2013) antara lain inflasi, BI Rate dan jumlah uang yang beredar (M2). Menurut Purnawan (2014) faktorfaktor yang mempengaruhi ISSI yaitu BI Rate, Inflasi, dan Exchange Rate (USD/IDR); dan makroekonomi global, yaitu Harga Minyak Dunia, Dow Jones Islamic Market Index US (IMUS), dan Hang Seng Index (HSI).

Pemodelan indeks saham dilakukan untuk mengetahui faktor-faktor yang berpengaruh terhadap indeks saham atau untuk memprediksi nilai indeks saham yang akan datang. Analisis regresi merupakan salah satu metode yang telah umum digunakan untuk memodelkan hubungan antara peubah penjelas dengan peubah respon pada data saham. Analisis regresi didasarkan pada asumsi-asumsi, sehingga tidak dapat selalu cocok dengan karakteristik data saham yang cenderung berfluktuatif. Pemodelan dengan analisis regresi dengan menggunakan data deret waktu seringkali menyebabkan asumsi kebebasan antar sisaan tidak terpenuhi (Montgomery et al. (2008)). Support Vector Regression (SVR) merupakan metode nonparametrik yang berbasis machine learning yang tidak memerlukan asumsi sehingga dapat digunakan untuk mengatasi batasan pada analisis regresi dengan data deret waktu.

SVR merupakan penerapan Support Vector Machine (SVM) untuk kasus regresi. Dalam kasus regresi, output yang digunakan adalah bilangan nyata atau kontinu (Mustakim et al. (2016)). Penelitian menggunakan SVR pernah dilakukan oleh Nida (2016) yang meneliti tentang peramalan data time series menggunakan support vector regression berdasarkan beberapa tipe kernel. Yasin et al. (2014) menggunakan SVR untuk meramalkan harga saham PT AXIATA XL dengan akurasi 92,47\% untuk data latih dan 83.39\% untuk data uji. Aglamaro (2011) meneliti tentang pemodelan statistical downscaling data GCM menggunakan SVR untuk memprediksi curah hujan bulanan Indramayu.

Peneliti harus menentukan parameter-parameter SVR seperti epsilon $(\varepsilon)$, cost (C), dan parameter untuk fungsi kernel. Permasalahan yang sering dihadapi adalah menentukan parameter-parameter yang optimal untuk menghasilkan model terbaik. 
Penentuan parameter yang optimal tersebut dapat diatasi dengan menggunakan algoritme grid search. Dengan demikian pada penelitian ini akan dilakukan pemodelan indeks saham syariah indonesia (ISSI) menggunakan support vector regression (SVR) dengan algoritme grid search menggunakan faktor-faktor BI Rate, kurs, dan jumlah uang yang beredar.

Tujuan penelitian ini adalah menerapkan metode support vector regression (SVR) dengan algoritme grid search untuk mencari model indeks saham syariah indonesia (ISSI) yang terbaik.

\section{Support Vector Regression}

SVR merupakan penerapan SVM untuk kasus regresi. Dalam kasus regresi, output yang digunakan adalah bilangan nyata atau kontinu.Smola and Scholkopf (2004) menjelaskan tentang SVR dengan memisalkan sebuah set data latih $\left\{\left(x_{1}, y_{1}\right), \ldots,\left(x_{n}, y_{n}\right)\right\} \subset X \times \mathbf{R}$ dimana $X$ merupakan ruang input, (misal $\left.X=R^{d}\right)$. Dalam SVR, tujuan yang akan dicapai adalah untuk menemukan fungsi $f(x)$ yang mempunyai simpangan $\varepsilon$ yang paling besar dari target aktual $y_{i}$ untuk keseluruhan data latih dan pada saat yang sama juga dicari fungsi yang serata mungkin. Dengan demikian, semua kesalahan (selisih antara output fungsi dengan target aktual) akan diabaikan asalkan nilainya kurang dari $\varepsilon$, namun tidak akan menerima semua kesalahan yang lebih besar dari $\varepsilon$. Misal $\mathrm{f}(\mathbf{x})$ adalah fungsi linier(Hyperlane) dalam bentuk berikut :

$$
f(\mathbf{x})=\mathbf{w}^{t} \mathbf{x}+b
$$

Keterangan:

$\mathbf{w}=$ vektor pembobot;

$\mathbf{x} \quad=$ vektor data latih;

$b \quad=$ konstanta;

Kerataan (flatness) untuk fungsi pada persamaan (1) mempunyai pengertian pencarian sebuah nilai $\mathbf{w}$ yang minimum, yang salah satu caranya adalah dengan meminimalkan nilai norm dari $\mathbf{w}$, yaitu $\mathbf{w}^{t} \mathbf{w}$. Hal tersebut dapat dituliskan dalam permasalahan optimasi sebagai berikut:

$$
\min \frac{1}{2}\|\mathbf{w}\|^{2}
$$

yang memenuhi $\left\{\begin{array}{l}y_{i}-f(\mathbf{x}) \leq \varepsilon, i=1,2, \ldots, n \\ f(\mathbf{x})-y_{i} \leq \varepsilon, i=1,2, \ldots, n\end{array}\right.$

Keterangan:

$y_{i} \quad$ : nilai aktual periode ke-i

$f\left(x_{i}\right)$ : nilai dugaan periode ke-i

Peubah slack $\xi$ dan $\xi^{*}$ dapat digunakan untuk mengatasi kasus nilai amatan yang berada di luar batas $\varepsilon$. Permasalahan optimasi setelah ditambahkan peubah slack dapat diformulasikan sebagai berikut (Smola and Scholkopf (2004)) :

$$
\min \frac{1}{2}\|\mathbf{w}\|^{2}+C \sum_{i=1}^{l}\left(\xi_{i}+\xi_{i}^{*}\right)
$$


yang memenuhi : $\left\{\begin{array}{c}y_{i}-f(\mathbf{x}) \leq \varepsilon+\xi_{i} \\ f(\mathbf{x})-y_{i} \leq \varepsilon+\xi_{i}^{*} \\ \xi_{i}, \xi_{i}^{*} \geq 0\end{array}\right.$

Konstanta $C>0$ menentukan trade-off antara kerataan fungsi $\mathrm{f}$ dan batas $\varepsilon$. Semua periode yang berada di luar batas $\varepsilon$ akan dikalikan C. Penetapan nilai C yang besar berarti menekankan pentingnya faktor $\varepsilon$ dibandingkan faktor kerataan fungsi. Gambar 1 menggambarkan situasi secara grafis penambahan peubah slack $\xi$ dan $\xi^{*}$. Peubah slack yang terletak dalam selang $\varepsilon$ akan bernilai nol, kemudian semakin jauh jarak peubah slack terhadap batas $\varepsilon$ maka nilainya semakin besar. Support vector adalah titik-titik dalam data latih yang terletak tepat garis batas dan di luar batas $\varepsilon$. Semakin kecil nilai $\varepsilon$ akurasi semakin tinggi, jumlah support vector semakin banyak, dan nilai peubah slack juga semakin tinggi.

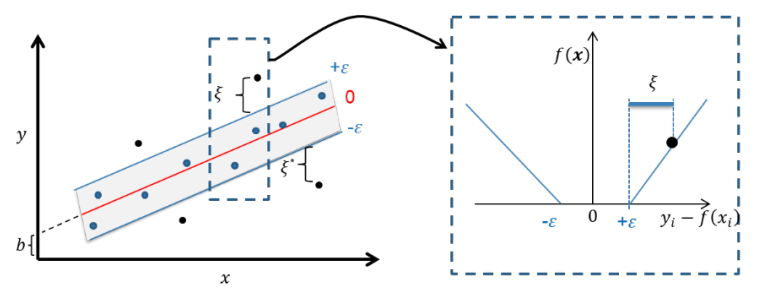

Gambar 1: Ilustrasi penambahan peubah slack

Solusi permasalahan optimasi Persamaan (3) dapat lebih mudah diselesaikan dengan fungsi lagrange berikut (Smola and Scholkopf (2004)):

$L=\frac{1}{2}\|\mathbf{w}\|+C \sum_{i=1}^{n}\left(\xi_{i}-\xi_{i}^{*}\right)-\sum_{i=1}^{n} \alpha_{i}\left(\varepsilon+\xi_{i}-y_{i}+f\left(\mathbf{x}_{\mathbf{i}}\right)\right)-\sum_{i=1}^{n} \alpha_{i}^{*}\left(\varepsilon+\xi_{i}^{*}+y_{i}-f\left(\mathbf{x}_{\mathbf{i}}\right)\right)-\sum_{i=1}^{n}\left(\eta_{i} \xi_{i}+\eta_{i}^{*} \xi_{i}^{*}\right)$

$\xi_{i}, \xi_{i}^{*}, \alpha_{i}$, dan $\alpha_{i}^{*}$ adalah Lagrange Multiplier digunakan untuk menyelesaikan masalah optimasi dengan kendala (contstrained optimization), di mana kendala tersebut akan dikonversi menjadi masalah optimasi tanpa kendala(unconstrained optimization). Pencarian nilai parameter persamaan hyperplane yang optimal ditentukan melalui turunan parsial fungsi lagrange terhadap $w, b, \xi, \xi^{*}$ sehingga $\mathrm{w}$ dan $\mathrm{b}$ dapat di cari menggunakan formula berikut:

$$
\begin{gathered}
w=\sum_{i=1}^{n}\left(\alpha_{i}-\alpha_{i}^{*}\right) x_{i} \\
b=y_{i}-w^{t} x_{i}-\varepsilon, 0<\alpha_{i}<C \\
b=y_{i}-w^{t} x_{i}+\varepsilon, 0<\alpha_{i}^{*}<C
\end{gathered}
$$

dengan:

$\mathbf{x}_{\mathbf{i}}=$ vektor peubah $\mathrm{x}$ periode ke-i

Permasalahan optimasi support vector dapat ditulis kembali sebagai berikut:

$$
\max \left\{\begin{array}{c}
-\frac{1}{2} \sum_{i, j=1}^{n}\left(\alpha_{i}-\alpha_{i}^{*}\right)\left(\alpha_{j}-\alpha_{j}^{*}\right) k\left(x_{i}, x_{j}\right)- \\
\varepsilon \sum_{i=1}^{n}\left(\alpha_{i}+\alpha_{i}^{*}\right)+\sum_{i=1}^{n} y_{i}\left(\alpha_{i}-\alpha_{i}^{*}\right)
\end{array}\right.
$$


yang memenuhi:

$\sum_{i=1}^{n}\left(\alpha_{i}-\alpha_{i}^{*}\right)=0$ dan $\alpha_{i}, \alpha_{i}^{*} \epsilon[0, C]$

Persamaan (1) dapat ditulis kembali sebagai berikut:

$$
f(x)=\sum_{i=1}^{n}\left(\alpha_{i}-\alpha_{i}^{*}\right) k\left(x_{i}, x\right)+b
$$

Keterangan :

$\alpha_{i}, \alpha_{i}^{*} \quad=$ pengali Lagrange;

$k\left(x_{i}, x\right) \quad=$ fungsi kernel;

$b \quad=$ konstanta;

Peneliti harus menentukan parameter epsilon $(\varepsilon)$ dan parameter cost $(\mathrm{C})$ pada kasus regresi(Cherkassky and Mulier (1998)). Kedua parameter tersebut berpotensi memengaruhi model akhir SVR yang terbentuk. SVR menggunakan fungsi kernel untuk mentransformasikan input non linear ke dalam ruang fitur yang dimensinya lebih tinggi kemudian diselesaikan secara linier. Peneliti harus memilih fungsi kernel yang akan digunakan dalam model SVR. Menurut (Yu et al. (2006)) fungsi kernel yang sering digunakan pada metode SVR adalah sebagai berikut:

1. Linier kernel:

$$
K\left(x_{i}, x_{j}\right)=x_{i} \cdot x_{j}
$$

2. Polynomial kernel:

$$
K\left(x_{i}, x_{j}\right)=\left(\left(x_{i} \cdot x_{j}\right)+1\right)^{d}
$$

d adalah derajat polinomial

3. Radial basis function (RBF) kernel:

$$
K\left(x_{i}, x_{j}\right)=\exp \left(-\gamma\left|x_{i}-x_{j}\right|^{2}\right)
$$

dengan $\gamma$ adalah parameter RBF kernel

\section{Algoritme Grid Search}

Metode grid search digunakan untuk mendapatkan model SVR dengan parameter C, $\varepsilon$, dan $\gamma$ yang optimal. Algoritme grid search memiliki cara kerja mencoba kombinasi parameter satu persatu dan membandingkan nilai galat terkecil parameter tersebut. Pasangan kombinasi dari parameter terlebih dahulu disimpan dalam grid-grid. Baris ke-i dan kolom ke-j yang nilai galat terkecil merupakan kombinasi parameter ke-i dan parameter ke-j terpilih (Aglamaro (2011)). Gambar 2 mengilustrasikan 2 parameter SVR yang akan dicari kombinasi parameter yang optimal menggunakan algoritme grid search.

\section{Metodologi}

\subsection{Data}

Data yang digunakan dalam penelitian ini adalah data sekunder, yaitu data bulanan dan mingguan indeks saham syariah Indonesia (ISSI) periode Agustus 2011 sampai dengan Maret 2018. Data ISSI bulanan merupakan harga penutupan pada hari terakhir setiap 


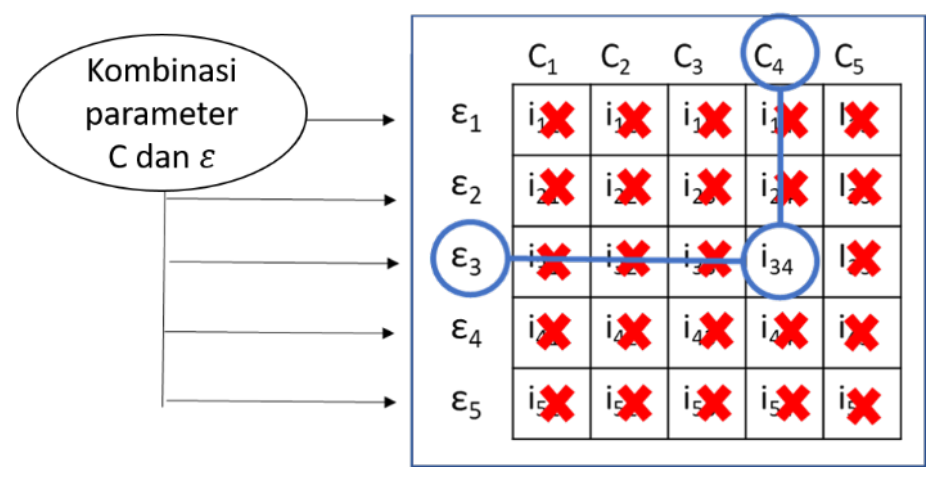

Gambar 2: Ilustrasi metode grid search

bulan yang terdiri dari 80 periode. Data ISSI mingguan merupakan harga penutupan pada hari kerja terkahir setiap minggu terdiri dari 343 periode. Data ISSI diperoleh dari situs id.investing.com. Selain ISSI digunakan juga beberapa peubah makro ekonomi sebagai peubah penjelas yaitu BI rate dan nilai kurs yang diperoleh dari Bank Indonesia, sedangkan jumlah uang yang beredar diperoleh dari Kementerian Perdagangan. BI Rate merupakan tingkat suku bunga acuan yang dikeluarkan oleh Bank Indonesia setiap bulan menggunakan satuan persen. Nilai tukar rupiah terhadap dolar Amerika pada penelitian ini adalah nilai kurs tengah yang merupakan rataan dari nilai kurs jual dan kurs beli bulanan. Jumlah uang beredar yang digunakan dalam penelitian ini adalah kategori M2. Dalam arti luas, M2 meliputi uang kartal (logam dan kertas), uang giral (cek) dan deposito berjangka. Peubah yang digunakan dalam penelitian ini dapat dilihat pada Tabel 1.

Tabel 1: Deskripsi peubah

\begin{tabular}{lrrr}
\hline Peubah & Notasi & Satuan & Periode \\
\hline ISSI & $Y$ & Poin & Bulanan, Mingguan \\
BI Rate & BIR & Persen & Bulanan \\
Jumlah uang beredar & JUB & Triliun & Bulanan \\
Nilai kurs & KUR & Rupiah & Bulanan, Mingguan \\
\hline
\end{tabular}

\subsection{Prosedur Analisis Data}

Analisis data dalam penelitian ini dibantu dengan perangkat lunak RStudio dengan menggunakan paket "e1710" dan "agricolae". Paket ini dapat mengakomodasi model SVM untuk kasus klasifikasi dan SVR untuk kasus regresi. Tahapan analisis data yang dilakukan dalam penelitian ini adalah sebagai berikut:

1. Melakukan eksplorasi data setiap peubah pada data bulanan dan data mingguan.

2. Menghitung korelasi antar peubah untuk data bulanan dan data mingguan.

3. Menentukan lag ISSI yang berpengaruh dengan menggunakan plot PACF pada data bulanan dan data mingguan.

4. Membuat model berdasarkan jenis periode data dan banyaknya periode yang digunakan. 
5. Membagi data menjadi dua bagian yaitu data latih dan data uji.

6. Melakukan pemodelan harga indeks menggunakan metode SVR dengan tahapan sebagai berikut:

(a) Menentukan fungsi kernel yang digunakan yaitu kernel linear,kernel polynomial, dan kernel Radial Basis Function.

(b) Melakukan $k$-fold cross validation dengan $k=10$.

K-fold cross validation merupakan salah satu variasi dari metode cross validation. K-fold cross validation dilakukan sebagai validasi model SVR. Inti validasi tipe ini adalah membagi data secara acak ke dalam $\mathrm{k}$ himpunan bagian. K-fold cross validation mengulang k-kali untuk membagi sebuah himpunan contoh secara acak menjadi $\mathrm{k}$ subset yang saling bebas, dari $\mathrm{k}$ himpunan bagian tersebut dipilih satu himpunan bagian menjadi data uji dan (k-1) bagian dijadikan data latih. Proses ini dilakukan berulang sebanyak k, dimana setiap $\mathrm{k}$ himpunan bagian yang ada menjadi data uji dan sisanya menjadi data latih. Ilustrasi proses validasi dapat dilihat pada Gambar 3.

\begin{tabular}{|c|c|c|c|c|} 
Tahap 1 & Data Uji & Data latih & Data latih & Data latih \\
Tahap 2 & Data latih & Data Uji & Data latih & Data latih \\
\hline Tahap 3 & Data latih & Data latih & Data Uji & Data latih \\
\hline Tahap 4 & Data latih & Data latih & Data latih & Data Uji \\
\hline
\end{tabular}

Gambar 3: Ilustrasi 4-fold cross validation

(c) Menentukan rentang nilai parameter-parameter untuk optimasi hyperplane pada data latih dengan menggunakan algoritme grid search untuk masing-masing fungsi kernel.

(d) Evaluasi model dengan membandingkan nilai korelasi dan RMSE model yang terbentuk.

Pengukuran akurasi hasil peramalan yang diperoleh dengan model SVR terhadap data ISSI menggunakan koefisien korelasi Pearson (r) dan root mean square error (RMSE). Model terbaik adalah model yang memiliki nilai koefisien korelasi Pearson yang mendekati 1 dan nilai RMSE yang mendekati 0. Koefisen korelasi Pearson dirumuskan sebagai berikut (Walpole (1992)):

$$
r=\frac{n \sum y_{i} \hat{y}_{i}-\sum y_{i} \sum \hat{y}_{i}}{\sqrt{\left(n \sum y_{i}{ }^{2}-\left(\sum y_{i}\right)^{2}\right)\left(n \sum \hat{y}_{i}{ }^{2}-\left(\sum \hat{y}_{i}\right)^{2}\right)}}
$$

Keterangan :

$\mathrm{r}=$ koefisien korelasi Pearson;

$y_{i}=$ nilai aktual pada waktu ke-i;

$\hat{y}_{i}=$ nilai dugaan pada waktu ke-i ;

Nilai kesalahan (error) digunakan untuk mengetahui besarnya simpangan nilai dugaan terhadap nilai aktual. Perhitungan galat menggunakan root mean square error (RMSE) dirumuskan oleh Walpole (1992) sebagai berikut: 


$$
R M S E=\sqrt{\frac{\sum_{i=1}^{n}\left(y_{i}-\hat{y}_{i}\right)^{2}}{n}}
$$

Keterangan:

$y_{i}=$ nilai aktual pada waktu ke-i;

$\hat{y}_{i}=$ nilai dugaan pada waktu ke-i;

\section{Hasil dan Pembahasan}

\subsection{Eksplorasi Data}

Eksplorasi terhadap ISSI dilakukan untuk mengetahui pola dan karakteristik dari data ISSI. Periode pengamatan ISSI dilakukan dari bulan Agustus 2011 hingga bulan Maret 2018. Perkembangan ISSI ditunjukkan oleh Gambar 4.

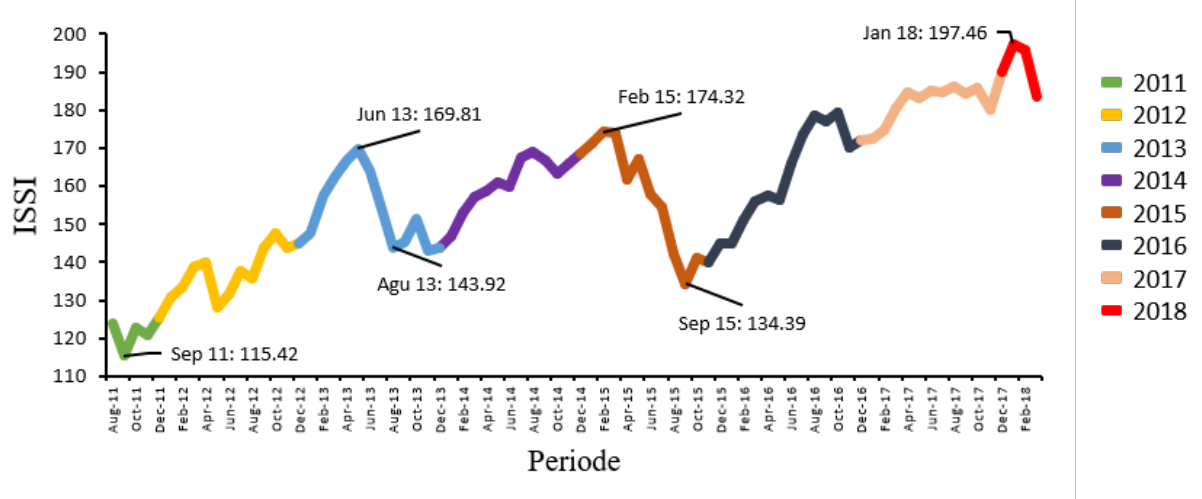

Gambar 4: Nilai ISSI Periode Agustus 2011-Maret 2018

ISSI cenderung mengalami tren kenaikan walaupun berfluktuasi. ISSI ditutup pada posisi 183.59 poin di akhir bulan Maret 2018 atau meningkat sebesar $47.96 \%$ dari periode Agustus 2011. Penurunan ISSI terbesar berada pada periode Februari 2015 September 2015 sebesar 39.93 poin, penurunan pada bulan september 2015 disebabkan oleh beberapa isu pemicu turunnya kepercayaan pelaku pasar modal, yaitu spekulasi atas kenaikan suku bunga acuan Bank Sentral Amerika Serikat atau The Fed, adanya tren penurunan harga minyak mentah dunia, serta tekanan perlambatan ekonomi global yang khususnya berasal dari negara China. Kenaikan tertinggi ISSI berada pada periode September 2015 - Januari 2018 sebesar 63.07 poin, kenaikan sebesar 4\% dari periode sebelumnya dipicu karena optimisme para investor akan perkembangan ekonomi Indonesia yang baik, selain itu sejumlah kegiatan besar yang akan terjadi pada tahun 2018 seperti piala dunia, pemilihan kepala daerah (Pilkada) dan Asian Games turut mendorong investor untuk menginvestasikan dananya pada saham.

Untuk melihat pola hubungan antara peubah respon dengan masing-masing peubah penjelas digunakan plot pencar. Pada Gambar 5(a) terlihat bahwa pola hubungan antara ISSI dengan BI Rate cenderung negatif. Hal ini menandakan bahwa semakin besar BI Rate, maka semakin kecil nilai ISSI. Hal ini sejalan dengan teori yang ada bahwa kenaikan BI Rate akan membuat investor mengalihkan dananya kepada bank sehingga akan membuat harga saham akan turun akibat jumlah penawaran saham yang meningkat. Pada Gambar 5(b) pola plot data yang terbentuk dari ISSI dengan jumlah 
uang beredar cenderung positif dimana kenaikan jumlah uang beredar diikuti kenaikan ISSI. Hal ini menandakan jumlah uang beredar yang tinggi membuat masyarakat yang memiliki kelebihan dana cenderung menginvestasikan hartanya pada saham. Kemudian, pada Gambar 5(c) pola data yang terbentuk antara ISSI dengan nilai kurs cenderung menyebar pada saat nilai kurs yang rendah dan saat nilai kurs yang tinggi. Hal ini menandakan bahwa nilai ISSI tidak terlalu dipengaruhi oleh tinggi atau rendahnya nilai kurs, tapi ada kasus dimana kenaikan nilai kurs yang tinggi membuat nilai ISSI turun secara drastis. Jika dilihat, plot cenderung membentuk hubungan yang positif. Hal ini dapat disebabkan dana investasi banyak yang berasal dari luar negeri yang mata uangnya mengalami peningkatan.
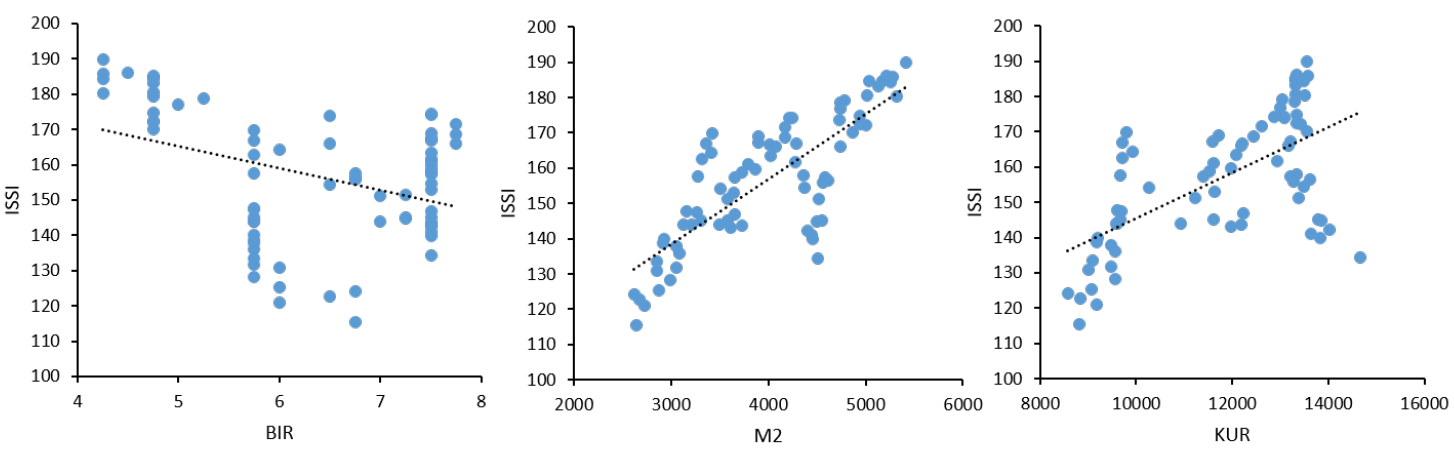

Gambar 5: Plot pencar antara ISSI dengan (a)BI Rate (b)jumlah uang beredar, dan (c)nilai kurs

\subsection{Korelasi}

Korelasi digunakan untuk menghitung besarnya keeratan hubungan antar dua peubah. Keeratan hubungan tersebut terlihat dari nilai korelasi, semakin mendekati 1 atau -1 maka keeratan hubungannya akan semakin tinggi. Tabel 2 memuat korelasi antara peubah penjelas dengan peubah respon serta korelasi antar peubah penjelas pada data bulanan.

Tabel 2: Nilai korelasi antar peubah

\begin{tabular}{lrrrr}
\hline & ISSI & BIR & JUB & KUR \\
\hline ISSI & 1.00 & & & \\
BIR & -0.38 & 1.00 & & \\
JUB & 0.80 & -0.30 & 1.00 & \\
KUR & 0.62 & 0.04 & 0.92 & 1.00 \\
\hline
\end{tabular}

Berdasarkan nilai korelasi peubah penjelas terhadap peubah respon data bulanan pada Tabel 2, nilai korelasi positif yang tinggi ditunjukkan oleh korelasi antara peubah ISSI dengan jumlah uang yang beredar dan nilai kurs. Korelasi antara BI Rate dengan peubah ISSI menunjukkan hubungan negatif yang lemah. Korelasi antar peubah penjelas memunyai nilai yang kecil, kecuali pada jumlah uang yang beredar terhadap nilai kurs yang memiliki korelasi sebesar 0.92 yang menunjukkan keeratan hubungan yang tinggi antara jumlah uang beredar dengan nilai kurs. Hal ini juga ditunjukkan oleh Tabel 3 dengan nilai VIF peubah M2 dan KUR berturut-turut sebesar 36.04 dan 31.17. 
Nilai VIF yang lebih dari 10 menunjukkan bahwa ada gejala multikolinearitas antara M2 dengan KUR perlu disikapi lebih serius, sehingga dilakukan pereduksian peubah dengan memilih peubah penjelas yang memiliki korelasi yang lebih tinggi terhadap peubah respon. Peubah jumlah uang dipilih karena memiliki nilai korelasi yang lebih tinggi terhadap ISSI yaitu sebesar 0.80. Nilai korelasi positif juga ditunjukkan hubungan antara ISSI dengan kurs pada data mingguan sebesar 0.65 .

Tabel 3: Nilai VIF peubah penjelas

\begin{tabular}{lr}
\hline Peubah & VIF \\
\hline BIR & 5.19 \\
JUB & 36.04 \\
KUR & 31.17 \\
\hline
\end{tabular}

\subsection{Penentuan Lag Berpengaruh}

Data ISSI merupakan data deret waktu dimana nilai amatan sekarang dapat dipengaruhi oleh nilai amatan periode sebelumnya (lag). Tujuan mencari lag yang berpengaruh adalah dijadikan sebagai peubah penjelas. Untuk mengetahui lag yang berpengaruh dapat menggunakan plot Partial Autocorrelation Function (PACF) dengan melihat lag yang signifikan, yaitu lag yang keluar dari garis batas signifikan. Lag signifikan dicari pada data bulanan dan data mingguan. Data mingguan dibuat dalam dua jenis data, yaitu data dengan 80 periode terakhir dan keseluruhan periode. Lag yang signifikan kemudian akan dijadikan peubah penjelas untuk masing-masing model yang akan dibentuk berdasarkan data yang dipakai. Berdasarkan hasil pada Gambar 6, terdapat lag pertama dan kedua yang keluar garis batas pada plot PACF sehingga lag yang akan dijadikan peubah penjelas pada data ISSI bulanan adalah lag pertama dan kedua. Pada Gambar 7 untuk data mingguan dengan 80 observasi terakhir terdapat lag pertama dan ketiga yang akan dijadikan peubah penjelas. Selanjutnya, pada Gambar 8 untuk data mingguan dengan 343 observasi yang akan dijadikan peubah penjelas adalah lag pertama dan keenam.

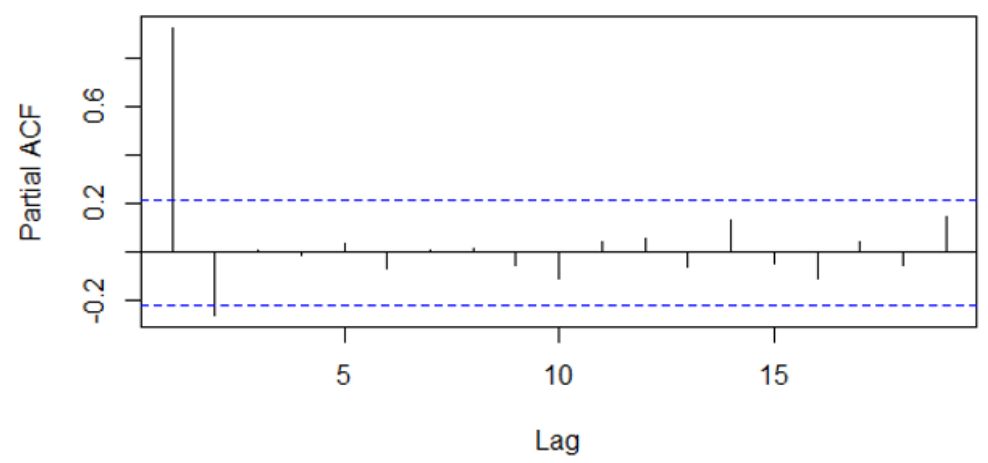

Gambar 6: Plot PACF ISSI data bulanan 


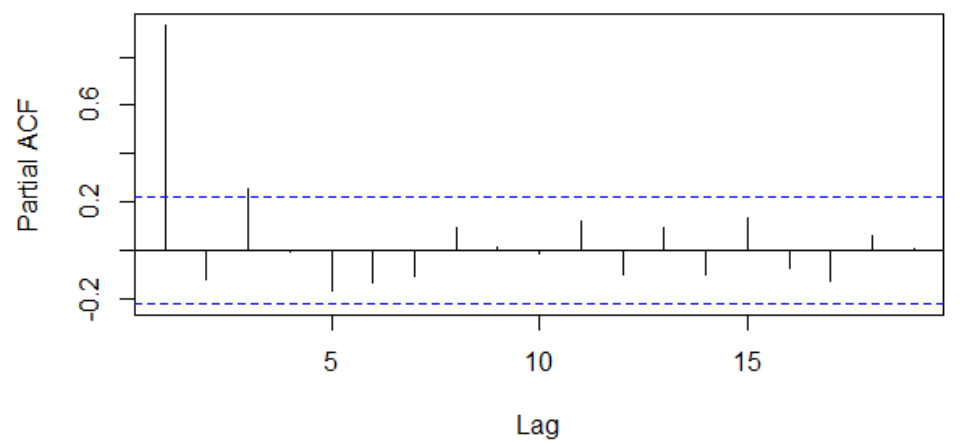

Gambar 7: Plot PACF data mingguan observasi 80

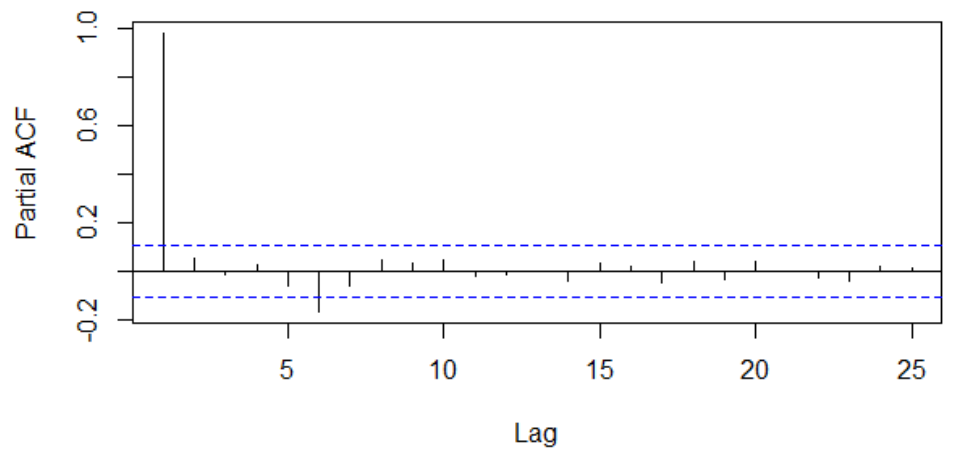

Gambar 8: Plot PACF data mingguan observasi 343

\subsection{Pemodelan Menggunakan SVR}

Pemodelan SVR diterapkan menjadi 4 model berdasarkan jenis periode yaitu data bulanan dan data mingguan. Selain jenis periode, panjang periode data juga menentukan model yang akan dibuat. Tabel 4 memuat model yang digunakan dalam penelitian ini.

Tabel 4: Model SVR yang digunakan dalam penelitian

\begin{tabular}{clcl}
\hline Model & Periode & Panjang Periode & Peubah Penjelas \\
\hline 1 & Bulanan & 80 & $\operatorname{lag} 1, \operatorname{lag} 2, \mathrm{BIR}, \mathrm{JUB}$ \\
2 & Bulanan & 80 & $\operatorname{lag} 1, \operatorname{lag} 2, \mathrm{KUR}$ \\
3 & Mingguan & 80 & $\operatorname{lag} 1, \operatorname{lag} 3, \mathrm{KUR}$ \\
4 & Mingguan & 343 & $\operatorname{lag} 1, \operatorname{lag} 6, \mathrm{KUR}$ \\
\hline
\end{tabular}

Setiap model diimplementasikan tiga fungsi kernel, yaitu Linear, Polynomial, dan Radial Basis Function (RBF). Parameter yang digunakan pada penelitian ini antara lain parameter cost $(\mathrm{C})$, epsilon $(\varepsilon)$, gamma $(\gamma)$, dan $\mathrm{d}$ (derajat polynomial). Proses validasi model pada percobaan ini menggunakan 10-fold cross validation. Pada setiap proses pelatihan dan pengujian data, dilakukan pemilihan parameter terbaik menggunakan algoritme grid search. 
Pada penelitian ini, nilai-nilai parameter yang diujicobakan untuk setiap model serta parameter terbaik yang terpilih untuk pengujian akhir adalah seperti pada Tabel 5 .

Tabel 5: Parameter percobaan model SVR

\begin{tabular}{lrrrr}
\hline Kernel & Nilai-Nilai Parameter & Model & \\
\hline RBF & $\varepsilon=0,0.01, \ldots, 0.3 \mathrm{C}=1,2, \ldots, 20 \gamma=2^{-7}, 2^{-6}, \ldots, 2^{1}$ & 1234 & $\varepsilon=0, \mathrm{C}=4, \gamma=2^{-1} \varepsilon$ \\
\hline Polynomial & $\varepsilon=0,0.01, \ldots, 0.3 \mathrm{C}=1,2, \ldots, 20 \mathrm{~d}=1,2$ & 1234 & $\varepsilon=0.21, \mathrm{C}=19, \mathrm{~d}$ \\
\hline Linier & $\varepsilon=0,0.01, \ldots, 0.3 \mathrm{C}=1,2, \ldots, 20$ & 1234 & \\
\hline
\end{tabular}

Tabel 6: Hasil Evaluasi model SVR data uji

\begin{tabular}{|c|c|c|c|}
\hline Model & Kernel & RMSE & $\mathbf{r}$ \\
\hline 1 & RBF Polynomial Linier & 14.5345 .9275 .925 & -0.1900 .4050 .405 \\
\hline 2 & RBF Polynomial Linier & 6.8695 .8185 .849 & $\begin{array}{lll}0.489 & 0.373 & 0.397\end{array}$ \\
\hline 3 & RBF Polynomial Linier & 8.7263 .6953 .652 & 0.6370 .8120 .788 \\
\hline 4 & RBF Polynomial Linier & 12.1922 .2932 .289 & -0.6220 .8720 .873 \\
\hline
\end{tabular}

Berdasarkan Tabel 6, model terbaik adalah menggunakan model 4 yang menggunakan data mingguan dengan jumlah observasi 343 serta kernel polynomial dengan $\varepsilon=0.12, \mathrm{C}=18$, dan $\mathrm{d}=1$ dengan nilai RMSE sebesar 2.29 dan nilai korelasi sebesar 0.870 pada data uji. Secara umum Kinerja yang dihasilkan oleh kernel linier dan kernel polynomial tidak berbeda jauh, namun karena model dengan kernel linier lebih sederhana maka yang dipilih sebagai model akhir adalah model dengan kernel linier. Plot perbandingan antara nilai aktual dan peramalan untuk model terbaik dapat dilihat pada Gambar 9.

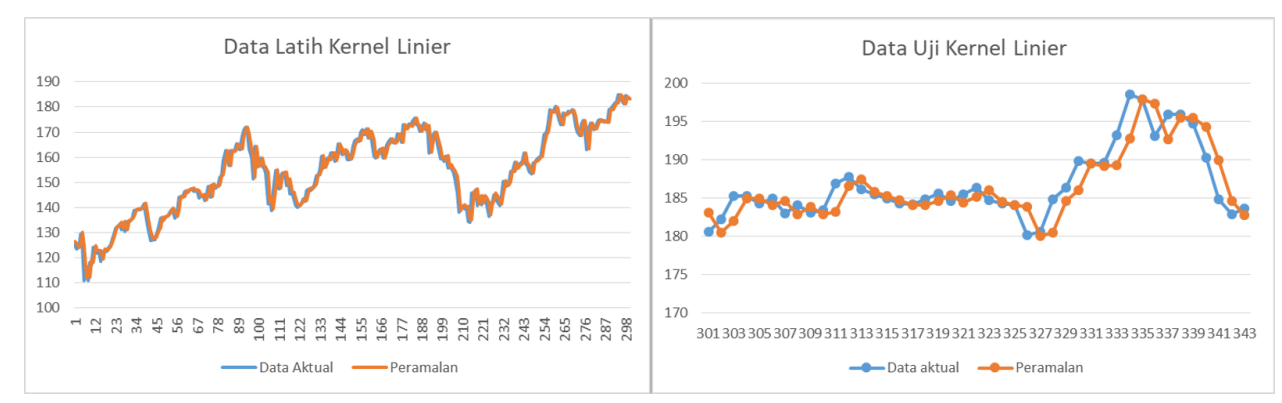

Gambar 9: Perbandingan nilai aktual dengan nilai peramalan data uji model 4 kernel linier

\section{Simpulan}

Simpulan dari penelitian ini adalah model Support Vector Regrresion dapat digunakan untuk memodelan ISSI. Secara umum model dengan menggunakan data bulanan kurang 
memberikan hasil yang baik dari pada model dengan data mingguan. Model SVR terbaik diperoleh dari model dengan kernel linier dengan parameter $\varepsilon=0.03$ dan $\mathrm{C}=2$. Evaluasi model SVR terbaik adalah nilai RMSE sebesar 2.289 dan nilai korelasi sebesar 0.873 untuk data uji.

\section{Daftar Pustaka}

Aglamaro, M. A. (2011). Pemodelan Statistical Downscaling Data GCM Mengunakan Support Vector Regression untuk Memprediksi Curah Hujan Bulanan Indramayu [Thesis], IPB, Bogor.

BEI (2018). Indeks Saham Syariah.

URL:

www.idx.co.id/id-id/beranda/produkdanlayanan/ pasarsyariah/indekssahamsyariah.aspx

Cherkassky, V. and Mulier, F. (1998). Learning From Data, John Wiley and Sons, Inc, Canada.

Montgomery, D. C., Jennings, C. L. and Kulahci, M. (2008). Introduction to Time Series Analysis and Forecasting, John Wileyand Sons, Inc, Canada.

Mustakim, Buono, A. and Hermadi, I. (2016). Performance comparison between support vector regression and artificial neural network for prediction of oil palm production, JIKI 9(1): 1-8.

URL: doi: 10.21609/jiki.v9i1.287

Nida, O. S. (2016). Forecasting of Time Series Data Using Support Vector Regression Based on Kernel Types [Skripsi], IPB, Bogor.

Pasaribu, R. B. F. and Firdaus, M. (2013). Analisis pengaruh variabel makroekonomi terhadap indeks saham syariah indonesia, JEB 7(2): 77-148.

Purnawan, I. (2014). Analisis Pengaruh Makroekonomi Domestik dan Makroekonomi Global terhadap Indeks Saham Syariah Indonesia (ISSI) Periode 2011-2014 [Skripsi], IPB, Bogor.

Smola, A. J. and Scholkopf, B. (2004). A tutorial on support vector regression, Statistics and Computing Kluwer Academic Pub 14 pp. 199-222.

Walpole, E. R. (1992). Pengantar Statistika Edisi ke-3, Gramedia, Jakarta.

Yasin, H., Prahutama, A. and Utami, T. W. (2014). Prediksi harga saham menggunakan support vector regression dengan algoritma grid search, Media Statistika 7(1): 29-35.

Yu, P. S., Chen, S. T. and Chang, I. F. (2006). Support vector regression for real-time flood stage forecasting, Journal of Hydrology 328: 704-716.

URL: doi:10.1016/j.jhydrol.2006.01.021 